UDC 378.015.62

DOI: https://doi.org/10.31470/2415-3729-2020-12-45-65

\title{
Monitoring the Quality of the Initial Performance of the Potential Engineer-Pedagogues as a Pedagogical Problem
}

\section{Roman Horbatiuk}

Doctor of Sciences in Pedagogy, Professor,

Department of Mechanical Engineering and Transport,

Ternopil Volodymyr Hnatiuk National Pedagogical University,

$\triangle 2$, Maksyma Kryvonosa Str., Ternopil, Ukraine, 46027

E-mail: gorbaroman@gmail.com

ORCID: http://orcid.org/0000-0002-1497-1866

\section{Vitalii Kabak}

Doctor of Philosophy in Pedagogy (Ph.D), Associate Professor, Department of Professional Education and Computer Technology, Lutsk National Technical University,

$\bowtie 56$, Potebni, Lutsk, Ukraine, 43018

E-mail: kabak.volyn@gmail.com

ORCID: http://orcid.org/0000-0001-9823-825X

Date of receipt of the article: September 28, 2020 Article accepted for publication: November 22, 2020

\section{Моніторинг якості навчальної діяльності майбутніх інженерів-педагогів як педагогічна проблема}

\section{Роман Михайлович Горбатюк}

доктор педагогічних наук, професор, кафедра машинознавства і транспорту, Тернопільський національний педагогічний університет ім. В. Гнатюка 
$\checkmark$ вул. вул. Максима Кривоноса, 2, м. Тернопіль, Україна, 46027

\section{Віталій Васильович Кабак}

кандидат педагогічних наук, доцент, кафедра професійної освіти та комп'ютерних технологій, Луцький національний технічний університет

$\checkmark$ вул. Потебні,56, м. Луцьк, Україна, 43018

Дата надходження статті: 28 вересня 2020 р. Стаття прийнята до друку: 22 листопада 2020 р.

\section{Abstract}

The article reveals the concept of the monitoring the quality of future engineer-pedagogues' educational activities and outlines the approaches to its determination in the current studies on the basis of psychological and pedagogical literature analysis. The purpose of the article is to determine the essential characteristics of the concept of monitoring the quality of future engineer-pedagogues educational activities, its capabilities and areas of implementation in the process of their professional training. The research methods are analysis of psychological and pedagogical sources and results of scientific research, questionnaire, testing of academic success, observation, analysis of reporting documentation and statistical data of educational institutions.

The results. The benefit of the study is that the notion of monitoring within the system of training the experts of engineering and pedagogical specialities has been defined as the process of continuous, scientifically justified, diagnostic and prognostic, targeted and activity-based supervision over the state and didactic process development of students in order to select optimal professionally-oriented tasks, means, and methods how the assignments are carried out. The authors analyze the principal stages of monitoring the quality of future engineer-pedagogues' 
educational activities within the system of higher education by means of formation of students' general and special (professional) competencies during acquiring a number of educational components oriented towards their further professional activities. The authors describe the key role of monitoring the quality of future engineer-pedagogues' educational activities as an instrument used to obtain integral vision about the quality of training of students of engineering and pedagogical specialities and the necessity to perform such procedure systematically. The article presents the results of survey questionnaire designed for teachers and students about the types of control (input (preliminary), current, progress, and final) while monitoring the quality of future engineer-pedagogues' educational activities. Conclusions. The main attention should be given to the necessity to provide flexible and variable forms, methods, and means of control while monitoring the quality of future engineerpedagogues' educational activities; to the role of teaching staff in this process, including stimulation, control and encouragement of students' cognitive activities, contributing the individualization of educational process.

Keywords: educational activities, monitoring, future engineer-pedagogues training, knowledge control, students.

\section{References}

1. Boichuk, I. D. (2014). Monitorynh yakosti osvity yak skladova pidhotovky suchasnoho fakhivtsia [Monitoring the quality of education as a component of training a modern specialist]. Problemy inzhenerno-pedahohichnoi osvity Problems of engineering and pedagogical education, 45, 81-86 [in Ukrainian].

2. Bordovskij, T. A., Nesterov, A. A., Trapicyn, S. Yu. (2011). Upravlenie kachestvom obrazovatel'nogo processa [Quality management of the educational process]. Sankt-Petersburg : Publishing House of Herzen [in Russian].

3. Kaidalova, L. H. (2007). Monitorynh yakosti profesiinoi pidhotovky inzheneriv-tekhnolohiv. [Monitoring the quality of 
professional training of technological engineers]. Problemy inzhenerno-pedahohichnoi osvity - Problems of engineering and pedagogical education, 18-19, 51-56 [in Ukrainian].

4. Majorov, A. N. (1998). Monitoring v obrazovanii [Monitoring in education]. Sankt-Petersburg : Publishing House «Education-Culture» [in Russian].

5. Monitorynh yakosti osvity : svitovi dosiahnennia ta ukrainski perspektyvy [Monitoring the quality of education: global achievements and Ukrainian prospects]. (2004). In O. I. Noodles (Ed.). Kyiv: KIS [in Ukrainian].

6. Nemova, N. N. (1999). Eto modnoe slovechko «monitoring» [This is a buzzword - «monitoring»]. Direktor shkoly - School Director, 7, 23-32 [in Russian].

7. Olendr, T. M. (2011). Monitorynh yakosti pryrodnychonaukovoi osvity v universytetakh SShA [Monitoring the quality of science education in US universities]. Extended abstract of candidate's thesis. Ternopil [in Ukrainian].

8. Pro zatverdzhennia Poriadku provedennia monitorynhu yakosti osvity [On approval of the Procedure for monitoring the quality of education]. (2020). Retrieved from: https://zakon.rada.gov.ua/laws/show/z0154-20\#Text [in Ukrainian].

9. Khrykov, Ye. M. (2011). Teoretyko-metodolohichni zasady monitorynhu profesiinoi pidhotovky [Theoretical and methodological principles of professional training monitoring]. Retrieved from: http://www.profosvita.org.ua/ru/career/ articles/2.html [in Ukrainian].

\section{Вступ}

Моніторинг якості навчальної діяльності майбутнього фахівця забезпечує цілеспрямований процес поетапного аналізу послідовності формування його загальних та професійних (фахових) компетентностей, сприяє послідовному та завчасному здійсненню корегувальних дій під час їх професійної підготовки. 
Відповідно до наказу Міністерства освіти і науки України № 54 «Про затвердження Порядку проведення моніторингу якості освіти» від 16.01.2020 року моніторинг проводиться з метою виявлення та відстеження тенденцій у розвитку якості освіти в країні, на окремих територіях, у закладах освіти, встановлення відповідності фактичних результатів освітньої діяльності ऑiі заявленим цілям, оцінювання причин відхилень від цілей відповідно до таких принципів: систематичності та системності; доцільності; прозорості моніторингових процедур та відкритості; безпеки персональних даних; об'єктивності одержання та аналізу інформації під час моніторингу; відповідального ставлення до своєї діяльності суб'єктів, які беруть участь у підготовці та проведенні моніторингу (Про затвердження Порядку проведення моніторингу якості освіти, 2020).

Проблеми моніторингу якості освіти досліджували у своїх працях Н. Вербицька, В. Горб, К. Краснянська, Т. Лукіна, 3. Рябова С. Сіліна та ін. Застосування моніторингу як складової навчальних досягнень студентів у ЗВО подано в наукових публікаціях О. Локшиної, Н. Байдацької, Л. Кайдалової, І. Булах та інших науковців.

На діагностичну направленість моніторингу в своїх працях вказують О. Абдуліна, В. Андрєєв, О. Бєлкін, В. Безпалько, В. Воловник, Л. Виготський, В. Ландсман та ін. На тотожності термінів «моніторинг» і «оцінювання» наголошують такі вчені, як: Н. Буркіна, О. Локшина, Т. Лукіна, Г. Сиротинко, 3. Слєпкань та ін. Досліджуючи дане питання Д. Матрос, Д. Полєв, Н. Мельников акцентують увагу на контролюючій направленості моніторингу (Олендр, 2011).

Аналізуючи сутнісну характеристику поняття моніторингу зазначимо, що однозначного тлумачення його серед вітчизняних і зарубіжних науковців немає. Зокрема, в оксфордському словнику під моніторингом розуміються ретельні спостереження, контроль за працею. Дане поняття Н. Нємова трактує як постійне спостереження за певним 
процесом з метою виявлення його відповідності бажаному результатові або заздалегідь висунутому припущенню (Немова, 1999: 27).

Досліджуючи питання якості професійної підготовки майбутніх фахівців, Є. Хриков визначає сутність поняття «моніторинг» як систему заходів, спрямованих на збір й аналіз інформації з метою вивчення та оцінювання якості підготовки фахівців і прийняття рішень щодо розвитку навчально-виховного процесу на основі аналізу виявлених типових особливостей і тенденцій (Хриков, 2011).

Грунтовне i досить цілісне визначення поняття моніторингу в освіті дав О. Майоров. Під даною дефініцією науковець розуміє цілісну систему «збирання, опрацювання, зберігання і поширення відомостей про освітню систему або окремі iї елементи, яка орієнтована на інформаційне забезпечення управління, дозволяє робити висновки про стан об'єкта у будь-який момент часу і дає прогноз його розвитку» (Майоров, 1998: 121).

Оскільки поняття «моніторинг» використовується науковцями в рамках різних наукових сфер - у практичній підготовці майбутніх фахівців, як спосіб дослідження реальності, прогнозування за допомогою своєчасної та якісної інформації, то можна погодитися з визначенням моніторингу, що представлене у психолого-педагогічному словнику, а саме: це «комплекс спостережень і досліджень, які визначають зміни в навколишньому середовищі, що викликаються діяльністю людини» (Кайдалова, 2007: 52).

Актуальність питання моніторингу якості навчальної діяльності майбутніх інженерів-педагогів, яке визначається як інструмент аналізу виміру набутого професіоналізму майбутніх фахівців у сучасних умовах, $є$ незаперечним, оскільки сприяє вистежуванню не тільки рівня підготовки майбутніх фахівців інженерно-педагогічних спеціальностей, але й визначити шляхи його поліпшення й подальшого вдосконалення. 
У межах структурного підрозділу закладу освіти застосовується педагогічний моніторинг, що передбачає супровідний контроль i поточне коригування взаємодії викладача і студента в процесі організації та безпосередньої реалізації освітнього процесу. Зокрема такий різновид моніторингу на рівні випускової кафедри, що є ключовою структурною одиницею ЗВО, фіксується у вигляді систематичного узагальнення їі діяльності щодо досягнення поставленої перед нею мети, а також діяльності та успішності кожного студента, формується прогностична інформація з її педагогічною інтерпретацією.

Моніторинг якості навчальної діяльності майбутніх інженерів-педагогів - це сукупність безперервних контролюючих дій, спрямованих на отримання та аналіз інформації з метою оцінки якості їх підготовки й виявлення певних тенденцій, які дозволяють спостерігати й коригувати за необхідності просування студента від незнання до знання, та приймати рішення щодо розвитку освітнього процесу та можливих необхідних змін (Бойчук, 2014).

У системі підготовки фахівців інженерно-педагогічних спеціальностей під моніторингом якості навчальної діяльності майбутніх інженерів-педагогів, на нашу думку, слід розуміти процес безперервного, науково обгрунтованого, діагностико-прогностичного, планово-діяльнісного спостереження за станом і розвитком дидактичного процесу здобувача вищої освіти 3 метою оптимального вибору професійно-орієнтованих завдань, засобів і методів їх виконання.

Проведений аналіз психолого-педагогічної літератури 3 проблематики дослідження показав, що на даний час питання моніторингу якості навчальної діяльності майбутніх інженерів-педагогів грунтовно не досліджено, хоча окремі його аспекти відображено в наукових статтях та розділах монографій. Тому актуальним $є$ питання теоретичного обгрунтування даної проблеми у процесі здійснення 
підготовки

студентів

інженерно-педагогічних спеціальностей. Враховуючи зазначене вище, метою статті $\epsilon$ визначення сутнісних характеристик поняття моніторингу якості навчальної діяльності майбутніх інженерів-педагогів, його можливостей та напрямів реалізації у процесі їх фахової підготовки.

\section{Матеріал і методи дослідження}

У процесі здійснення дослідницької діяльності нами було використано аналіз психолого-педагогічних джерел та результатів проведених наукових пошуків щодо підготовки майбутніх інженерів-педагогів i формування у них професійних (фахових) компетентностей під час вивчення професійно-орієнтованих дисциплін у закладах вищої освіти. На етапі безпосереднього моніторингу якості навчальної діяльності майбутніх інженерів-педагогів було застосовано опитування здобувачів освіти та викладачів (анкетування), тестування успішності навчання, спостереження за освітнім процесом та освітньою діяльністю у закладах вищої освіти, аналіз звітної документації й статистичних даних закладів освіти про якісні показники дидактичного процесу за встановленими формами звітності.

Порівняльний аналіз дав можливість стверджувати, що створення комплексу засобів моніторингу якості навчальної діяльності майбутніх інженерів-педагогів (анкети, тестові завдання, засоби підсумкового контролю знань, статистичні дані та ін.) є запорукою успішного здійснення коригувальних дій задля забезпечення якості підготовки здобувачів вищої освіти інженерно-педагогічних спеціальностей.

\section{Результати та їх обговорення}

Прийняття нових стандартів вищої освіти та реалізація на їх основі нових освітніх програм зобов'язує науковопедагогічних працівників використовувати такі єдині форми контролю освітнього процесу, які б максимально відображали реальний стан справ у підготовці майбутніх фахівців, а його результати були б порівнюваними. Це, в 
свою чергу, забезпечує кореляцію навчальної діяльності майбутніх інженерів-педагогів, вчасність та коректність внесення необхідних змін у діяльність як викладачів, так i студентів. Рівень підготовки фахівців інженернопедагогічних спеціальностей, їх компетентність, професійні якості, роль і місце в системі вищої та фахової передвищої освіти окреслені рамками конкретно діючих освітньопрофесійних програм (ОПП), за яких навчається студент, регулюється нормами академічної доброчесності та етичним кодексом (або кодексом честі) працівника закладу вищої освіти.

Моніторинг якості навчальної діяльності майбутніх інженерів-педагогів також може бути засобом для одержання цілісного уявлення про компетентність викладача, зокрема про його професійні якості та можливість забезпечення підготовки висококваліфікованого здобувача вищої освіти. Враховуючи зазначене, можемо відмітити, що моніторинг якості навчальної діяльності студента забезпечує здійснення поетапного аналізу, діагностики, прогнозування й проектування дидактичних процесів, взаємодії суб'єктів педагогічного процесу (Бойчук, 2014).

Моніторинг якості навчальної діяльності майбутніх інженерів-педагогів нами було досліджено на основі проведеного аналізу підготовки здобувачів освіти спеціальностей 015.39 Професійна освіта (Цифрові технологіï) i 015.20 Професійна освіта (Транспорт) Тернопільського національного педагогічного університету імені Володимира Гнатюка (ТНПУ) та Луцького національного технічного університету (ЛНТУ).

У даних закладах вищої освіти створена комплексна система із забезпечення моніторингу здобувачів освіти, що дає можливість адекватно контролювати початкову, поточну та підсумкову успішність студентів, проводити своєчасне коригування негативних відхилень. У процесі підготовки майбутніх інженерів-педагогів для здійснення моніторингу 
їх якості навчання на всіх етапах навчання застосовують такі види контролю: вхідний (попередній), поточний, проміжний та підсумковий.

Мета попереднього контролю полягає у встановленні вихідного рівня володіння загальними компетентностями здобувача освіти по завершенню ним закладу середньої освіти (на першому курсі підготовки майбутніх інженерівпедагогів), а також на початку вивчення нової навчальної дисципліни, визначенні індивідуальних особливостей окремого студента, що зможуть впливати на успішність навчання. Такий моніторинг забезпечується системою онлайн анкетування абітурієнтів за допомогою розроблених Google-форм, завдяки яким встановлюється спрямованість молодої особи до конкретної професійної діяльності. Також попередній контроль здійснюється кураторами-тьюторами на першому тижні навчання майбутніх інженерів-педагогів під час проведення виховних годин. Для забезпечення принципу порівнюваності для вхідного контролю використовують однакові, стандартизовані тестові матеріали. Аналіз отриманих результатів забезпечує диференціацію підготовки майбутнього фахівця i дозволяє, окреслити стратегії вивчення освітніх компонент загальної та професійної підготовки з урахуванням рівня знань студентів, що впливає на підвищення ефективності роботи викладача та прогнозовану якість професійної підготовки майбутнього фахівця загалом.

Поточний контроль дозволяє здійснювати моніторинг успішності набуття загальних і спеціальних (фахових) компетентностей $\mathrm{y}$ процесі вивчення майбутніми інженерами-педагогами навчальних дисциплін та забезпечення відповідних результатів навчання, передбачених освітньою програмою підготовки здобувачів вищої освіти. Такий різновид контролю навчальної діяльності здійснюється регулярно i спрямований на перевірку засвоєння студентами інженерно-педагогічних спеціальностей певної частини навчального матеріалу або 
рівня сформованості відповідних компетентностей з окремих видів професійної діяльності. Проводиться індивідуально кожним науково-педагогічним працівником у навчальних групах, де він реалізує дидактичний процес, із застосуванням розроблених педагогом авторських матеріалів. Для здійснення поточного контролю викладачами вказаних вище ЗВО найчастіше застосовуються тестові завдання (відкритого або закритого типу), індивідуальні та контрольні завдання, самостійні роботи тощо.

Реалізація проміжного виду контролю у процесі моніторингу якості підготовки майбутніх інженерів-педагогів проводиться наприкінці кожного змістового модуля i дозволяє робити висновки щодо якості та ефективності засвоєння дидактичного матеріалу. Модульний контроль проводиться викладачами, в основному, із застосуванням системи дистанційного навчання Moodle, відбувається у формі єдиного для всіх студентів тесту, що охоплює матеріал певного навчального модуля.

Завершальний етап моніторингу якості навчальної діяльності майбутніх інженерів-педагогів - це підсумковий контроль, що передбачає аналіз набутих студентами уніфікованих результатів навчання за певним освітнім компонентом (навчальною дисципліною), спрямований на встановлення рівня компетентності фахівця, якого було досягнуто в результаті засвоєння значного за обсягом матеріалу, проводиться наприкінці вивчення навчальної дисципліни у формі семестрового заліку або екзамену. Такий контроль спрямований на оцінювання навчальних досягнень здобувачів вищої освіти.

Систематичний контроль знань і вмінь студентів, як складова моніторингу їх діяльності, - одна з основних умов підвищення якості навчання майбутніх інженерів-педагогів. Досвідчений викладач у своїй повсякденній роботі повинен використовувати не тільки загальноприйняті форми (самостійна і контрольна роботи, усне опитування, реферати тощо) але і впроваджувати нові, адаптуючи їх для конкретної 
навчальної дисципліни або дидактичних умов. Оскільки будь-який вид контролю для студентів повинен бути, в першу чергу, повчальним - вміле володіння викладачем різними його методами сприяє підвищенню зацікавленості студентів, забезпечує активну роботу кожного здобувача освіти (Бордовський, 2011).

3 метою виявлення найбільш ефективних видів контролю навчальної діяльності студентів були складені анкети i, методом опитування викладачів і студентів ТНПУ i ЛНТУ, проведено моніторингове дослідження. За результатами опитування нами отримані результати дослідницької діяльності, які бути представлені у вигляді діаграм.

Так із відображених на рисунку 1 даних видно, що найкращим видом контролю знань для викладачів є поточний $(57,14 \%)$, другий за ефективністю вони вважають підсумковий $(21,43 \%)$, менш ефективні - вхідний i проміжний види контролю. Також потрібно відмітити, що думки науково-педагогічних працівників часто розбіжні в доцільності вхідного контролю вивчення навчальної дисципліни.

Викладачеві такий вид контролю у процесі моніторингу навчальної діяльності інженерів-педагогів дозволяє визначити рівень підготовленості групи для подальшого вивчення навчального курсу і встановити міжпредметні зв'язки. У зв'язку 3 тим, що науково-педагогічному працівнику необхідно вивчити програми суміжних курсів i розробляти контрольні завдання з урахуванням їх специфіки, механізм реалізації такого моніторингу може бути утруднений. Для оптимізації такої діяльності та усунення повторів контрольні завдання мають розроблятися колективом викладачів і можуть бути використані для різних видів контролю $з$ дисциплін, що вивчаються майбутніми інженерами-педагогами. Це унеможливить дублювання питань i, як наслідок, дозволить поліпшити якість викладання кожної дисципліни. 


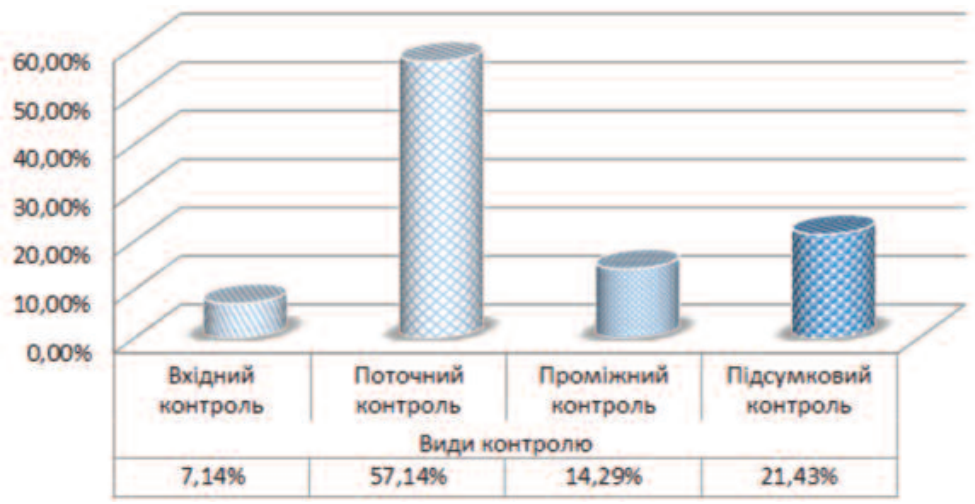

Рис. 1. Пріоритетність видів контролю під час моніторингу

У результаті проведеного опитування серед здобувачів вищої освіти та науково-педагогічних працівників було встановлено, що найбільш ефективним методом реалізації поточного контролю знань, на думку викладачів, $\epsilon$ гармонійне поєднання усного i письмового (або електронного) контролю знань $(64,0 \%)$. Аналогічне дослідження серед студентів відобразило інші результати для них найбільш ефективним методом контролю $є$ письмове (або електронне) опитування $-55,0$ \% опитаних (рис. 2).

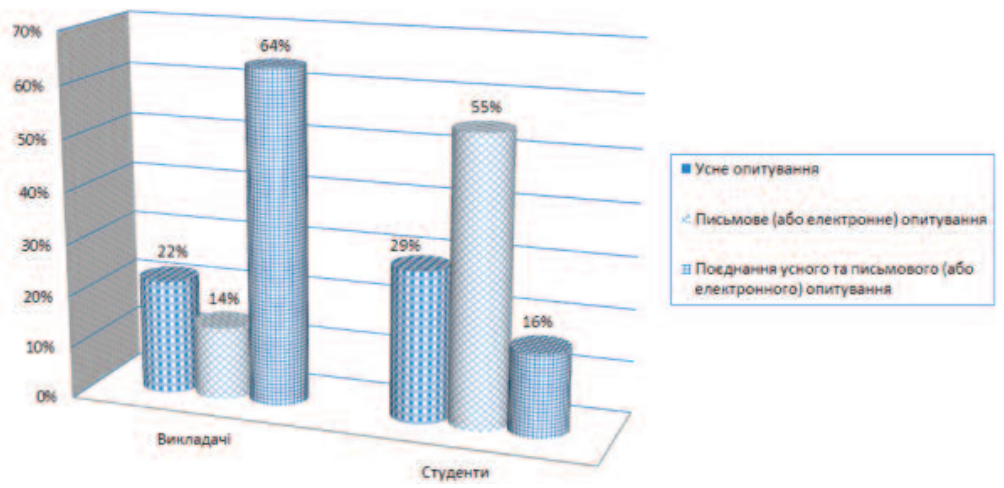

Рис. 2. Ефективність методів контролю серед викладачів і студентів 
За допомогою анкетного опитування були виявлені переваги і недоліки тестового контролю знань в системі Moodle. Серед викладачів ЗВО було встановлено, що усі вони притримуються тієї думки, а це є незаперечною перевагою електронного тестового контролю знань, економія часу (100,0 \% опитаних). Водночас до недоліків такого контролю, на думку викладачів, можна віднести елемент випадковості отриманих результатів (43,0 \%) і в багатьох випадках не обгрунтованість відповідей (64,0 \%).

Аналізуючи відповіді студентів нами було встановлено, що найбільшою перевагою тестового контролю знань в системі Moodle є те, що викладачі у процесі їх складання часто дають варіанти відповідей. Це підтвердили 92,0% студентів, а 8,0 \% вважають, що перевага тестового контролю знань - економія часу. Недоліками такого студенти вважають: елемент випадковості (35,0 \%), необ' єктивність оцінки знань (17,0 \%), некоректність поставлених питань (25,0 \%). Про відсутність недоліків тестового контролю знань в системі Moodle вказали 23 \% студентів.

Відповідаючи на запитання анкети про найбільш ефективні форми підсумкового контролю, були отримані такі відповіді: 57,14 \% викладачів вважають, що найбільш ефективною формою підсумкового контролю є екзамен, 42,86 \% - залік. Думка студентів щодо найбільш ефективної форми контролю розділилась практично в однакових співвідношеннях - 52,31 \% студентів вважають, що іспит, а 47,69 \% надають перевагу заліку. Як викладачі, так і студенти вважають, що під час оцінювання навчальної діяльності необхідно насамперед створити сприятливі умови для прояву і стимулювання особистісного потенціалу всіх учасників освітнього взаємодії.

Освітня діяльність майбутніх інженерів-педагогів може бути результативною лише в тому випадку, коли систематично і глибоко проводиться моніторинг якості навчання, коли самі студенти постійно бачать результат своєї 
роботи. Якщо такий контроль в процесі засвоєння навчального матеріалу відсутній, то студенти не знають справжнього рівня своїх знань, не чітко уявляють свої недоробки. Недоліком традиційного семестрового контролю знань для здобувачів вищої освіти $є$ те, що часто навіть сумлінного студента на екзамені може очікувати невдача. Сюди можна віднести також суб' єктивізм оцінювання знань викладачами, оскільки кожен 3 екзаменаторів має своє судження про знання майбутнього фахівця, визначає кількість додаткових питань та їх складність, свої методи і критерії оцінювання, що, в цілому, впливає на загальну оцінку.

Одним із ефективних способів моніторингу навчальної діяльності майбутніх інженерів-педагогів $\epsilon$ рейтингове оцінювання знань студентів, що передбачає систему накопичення умовних одиниць (балів) знань протягом усього навчального семестру. Такий підхід дозволяє в комплексі оцінити старанність студента, його навчальну активність й рівень засвоєння матеріалу.

Рейтингова система найбільш успішно реалізується на основі модульної побудови навчального матеріалу, а також рівнів можливих досягнень майбутніх інженерів-педагогів. У процесі формування рейтингової системи оцінювання вкрай важливо методично точно оцінити кожен вид навчальної роботи відповідним числом балів і встановити рейтинг, що відповідає тому чи іншому рівню знань здобувача вищої освіти. Оцінка 3 кожної дисципліни визначається за 100-бальною шкалою як сума балів, набраних студентом у результаті навчальної діяльності протягом семестру. При цьому для визначення рейтингу вводяться обов'язкові та додаткові бали. Обов'язковими балами оцінюється відвідування лекційних занять, робота на лабораторних (практичних) заняттях, виконання студентом контрольних робіт, рефератів, передбачених навчальним планом. Водночас до загального семестрового рейтингу 
враховуються досягнення студента понад навчальний план. Додаткові бали призначаються здобувачам освіти, наприклад, за участь в науково-дослідній роботі, виступах на всеукраїнських і міжнародних конференціях (семінарах), участь у позааудиторних заходах тощо.

Переваги рейтингової системи добре усвідомлюють та підтримують майбутні інженери-педагоги. Абсолютна більшість студентів (78,46 \%) позитивно ставиться до рейтингової системи оцінювання знань, 10,77 \% висловили негативне ставлення, 4,61 \% відповіли, що мають нейтральне ставлення, а 6,16 \% здобувачам вищої освіти складно було дати відповідь на поставлене питання (рис. 3).

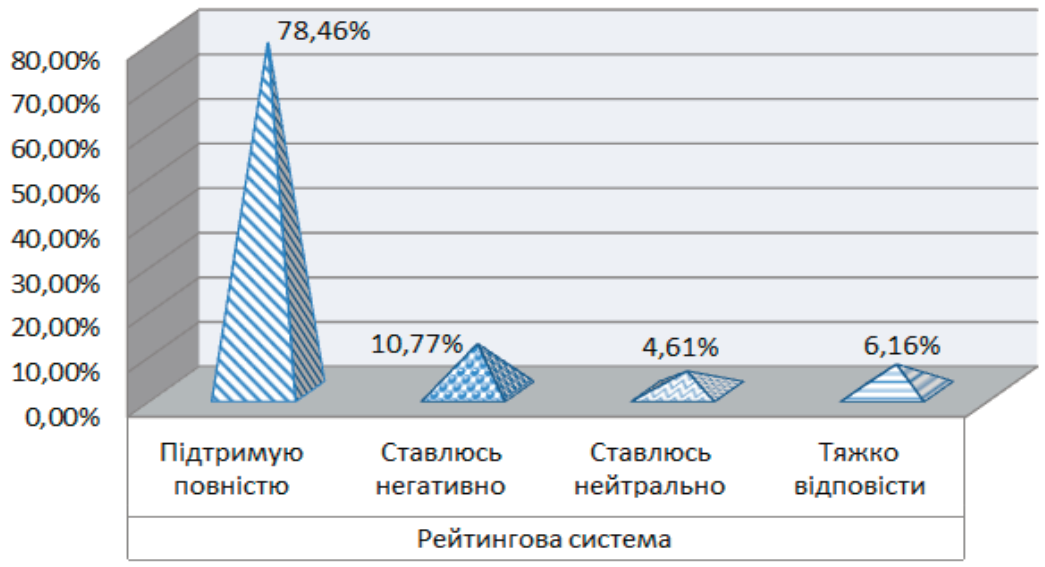

Рис. 3. Ставлення студентів до рейтингової системи

Застосування рейтингової системи на думку майбутніх інженерів-педагогів, стимулює роботу в семестрі $(41,5$ \%), дозволяє більш об'єктивно оцінювати знання (15,4%), створює зацікавленість до самостійної роботи, участь у поза аудиторній роботі (12,3\%). Але, безумовно, при рейтинговій системі основним стимулом для студентів стає можливість бути звільненими від семестрового іспиту (72,3\%).

Рейтингова система оцінювання створює надійне підгрунтя для моніторингу індивідуальних особливостей 
студента, сприяє систематичному засвоєнню знань. Отже, зростає зацікавленість і успішність студента, що робить освітній процес навчання більш ефективним.

\section{Висновки}

Моніторинг якості освітньої діяльності майбутніх інженерів-педагогів може бути використаний як один iз дієвих способів активізації роботи як студента, так i викладача. Він допомагає виробити стратегію навчання здобувачів вищої освіти 3 урахуванням їх потреб, можливостей і набутих професійних навичок. Викладач при цьому отримує можливість на основі аналізу отриманої інформації вибудовувати освітній процес, як сукупність форм i методів навчання для досягнення поставлених цілей, надання дієвої та оперативної допомоги майбутнім інженерам-педагогам в процесі навчання.

Система моніторингу якості навчання повинна носити систематичний характер i реалізовуватися у всіх його функціях, не обмежуючись лише контролюючою складовою. Форми, прийоми, методи і засоби контролю у процесі здійснення моніторингу навчальної діяльності майбутніх інженерів-педагогів повинні бути гнучкими і варіативними. Викладач зобов'язаний на кожному занятті, незалежно від теми, засобів i часу, стимулювати, контролювати i заохочувати пізнавальну діяльність здобувачів вищої освіти, підтримувати зворотний зв'язок протягом усього заняття. Завдяки цьому забезпечується індивідуалізація процесу навчання, яка закладена в самих умовах здійснення освітнього процесу (в межах навчальної групи, вивчення нового матеріалу, рівня підготовленості та набуття компетентностей здобувачами вищої освіти).

\section{Література}

1. Бойчук I. Д. Моніторинг якості освіти як складова підготовки сучасного фахівця. Проблеми інженернопедагогічної освіти. 2014. № 45. С. 81-86. 
2. Бордовский Т. А., Нестеров А. А., Трапицын С. Ю. Управление качеством образовательного прочесса: монография. Санкт-Петербург : Изд-во РГПУ им. А. И. Герцена, 2011. 359 с.

3. Кайдалова Л. Г. Моніторинг якості професійної підготовки інженерів-технологів. Проблеми інженернопедагогічної освіти. 2007. № 18-19. С. 51-56.

4. Майоров А. Н. Мониторинг в образовании. Книга 1. Санкт-Петербург : Издательство «Образование-Культура», 1998. $344 \mathrm{c}$.

5. Моніторинг якості освіти : світові досягнення та украйнські перспективи / ра заг. ред.О. І. Локшиної. Київ : K.I.C., 2004. 128 c.

6. Немова Н. Н. Это модное словечко - «мониторинг». Директор школи. 1999. №7. С. 23-32.

7. Олендр Т. М. Моніторинг якості природничо-наукової освіти в університетах США : автореф. дис. ... канд. пед.наук : 13.00.01 / ТНПУ ім. В. Гнатюка. Тернопіль, 2011. 22 с.

8. Про затвердження Порядку проведення моніторингу якості освіти. URL: https://zakon.rada.gov.ua/laws/show/z015420\#Техt (Дата звернення: 06.09.2020).

9. Хриков С. М. Теоретико-методологічні засади моніторингу професійної підготовки. URL: http://www.profosvita.org.ua/ru/career/articles/2.html (Дата звернення: 07.09.2020).

\section{Горбатюк Р.М., Кабак В.В.}

\section{Моніторинг якості навчальної діяльності майбутніх інженерів-педагогів як педагогічна проблема}

\section{Анотація}

У статті розкрито сутність поняття моніторингу якості навчальної діяльності майбутніх інженерів-педагогів та на 
основі аналізу психолого-педагогічної літератури встановлено підходи до його тлумачення в сучасних наукових дослідженнях. Подано узагальнене визначення моніторингу в системі підготовки фахівців інженерно-педагогічних спеціальностей, під яким, слід розуміти процес безперервного, науково обгрунтованого, діагностикопрогностичного, планово-діяльнісного спостереження за станом і розвитком дидактичного процесу здобувача освіти 3 метою оптимального вибору професійно-орієнтованих завдань, засобів і методів їх виконання.

Подано авторське бачення основних етапів здійснення моніторингу якості професійної діяльності майбутніх інженерів-педагогів в системі вищої освіти шляхом формування загальних та спеціальних (фахових) компетентностей здобувачів освіти в умовах опанування освітніх компонентів, які спрямовані на подальшу професійну діяльність їх як кваліфікованих фахівців.

Визначено ключову роль моніторингу навчальної діяльності майбутніх інженерів-педагогів, як засобу, для одержання цілісного уявлення про якість підготовки студентів інженерно-педагогічних спеціальностей та необхідність систематичного характеру його проведення.

Представлено результати проведеного опитування викладачів та студентів щодо видів контролю (вхідний (попередній), поточний, проміжний та підсумковий) у процесі здійснення моніторингу якості навчальної діяльності майбутніх інженерів-педагогів. Акцентовано увагу на необхідності забезпечення гнучких і варіативних форм, прийомів, методів і засобів контролю у процесі здійснення моніторингу навчання здобувачів освіти.

Підкреслено ключову роль викладача у процесі підготовки майбутнього інженера-педагога, діяльність якого має бути спрямована на стимулювання, контроль i заохочення пізнавальної діяльності здобувачів освіти, забезпечуючи індивідуалізацію процесу навчання, яка закладена в умовах здійснення дидактичного процесу. 
Ключові слова: навчальна діяльність, моніторинг, підготовка інженерів-педагогів, контроль знань, здобувачі освіти.

\section{Горбатюк Р.М., Кабак В.В.}

\section{Мониторинг качества учебной деятельности будущих инженеров-педагогов как педагогическая проблема}

\section{Аннотация}

В статье раскрыта сущность понятия мониторинг качества учебной деятельности будущих инженеровпедагогов и на основе анализа психолого-педагогической литературы установлены подходы к его толкованию в современных научных исследованиях. Дано обобщенное определение мониторинга в системе подготовки специалистов инженерно-педагогических специальностей, под которым следует понимать процесс непрерывного, научно-обоснованного, диагностико-прогностического, планово-деятельностного наблюдения за состоянием и развитием дидактического процесса соискателя образования с целью оптимального выбора профессиональноориентированных задач, средств и методов их выполнения.

Представлено авторское видение основных этапов осуществления мониторинга качества профессиональной деятельности будущих инженеров-педагогов в системе высшего образования путем формирования общих и специальных (профессиональных) компетенций соискателей образования в условиях освоения образовательных компонентов, направленных на дальнейшую профессиональную деятельность их как квалифицированных специалистов.

Определена ключевая роль мониторинга учебной деятельности будущих инженеров-педагогов как средства для получения целостного представления о качестве 
ПОдГОТОВКИ

студентов

инженерно-педагогических

специальностей и необходимость систематического характера его проведения.

Представлены результаты проведенного опроса преподавателей и студентов, по видам контроля (входной (предварительный), текущий, промежуточный и итоговый) в процессе осуществления мониторинга качества учебной деятельности будущих инженеров-педагогов. Акцентировано внимание на необходимости обеспечения гибких и вариативных форм, приемов, методов и средств контроля в процессе осуществления мониторинга обучение соискателей образования.

Подчеркнуто ключевую роль преподавателя в процессе подготовки будущего инженера-педагога, деятельность которого должна быть направлена на стимулирование, контроль и поощрение познавательной деятельности соискателей образования, обеспечивая индивидуализацию процесса обучения, которая заложена в условиях осуществления дидактического процесса.

Ключевые слова: учебная деятельность, мониторинг, подготовка инженеров-педагогов, контроль знаний, соискатели образования. 